\title{
The influence of the ascriptive statuses at the intensity of students' educational practices
}

\author{
Roman Borysov, Iryna Sheremet, V. N. Karazin Kharkiv National University
}

The article deals with the influence of the Ukrainian students' ascriptive statuses on the course of their professional socialization. There are are students' status positions, educational dispositions and the content and focus of the educational process among the factors of professional socialization. The ascriptive statuses are considered as social indicators which may restrict the access of the students to the tertiary education. A number of ascriptive statuses, which may have the restrictive influence, are identified, among which are the sex, the economic and cultural capital of the family, place of living before the admission to higher education. It was listed the signs of student heterogeneity as a socio-demographic group. The education of students in higher education institutions is considered with the prism of acquiring the competences obtained as a result of the implementation of educational practices. The professional socialization is considered as the process of the acquisition of the professional competences during the process of the implementation of the educational practices. The notion of the professional practice is applied from the standpoint of P. Bourdieu's Constructivist Structuralism and is defined as routineized unconscious acts which are repeated in time and are aimed at the realization of the strategy of the achieving the goal within a certain sphere of social reality. The authors refer to the results of a quantitative survey of Ukrainian students to determine the degree of influence of ascriptive statuses on the process of professional socialization in universities. The relationship between the intensity of educational practices contributing to the learning process and academic achievement is analyzed. The existence and hierarchy of educational practices from the point of view of their effectiveness is identified and characterized. The conclusion is made that there is a significant impact of the set of the students' ascriptive statuses on the course of the professional socialization. As a result the cultural capital of a family of students has the highest "capital intensivity" in comparison with other ascriptive statuses.

Keywords: ascriptive statuses, higher education, professional socialization, educational practices, Constructivist Structuralism, student-centered education

\section{Вплив статусів припису на інтенсивність навчальної практики студентів}

\section{Роман Борисов, Ірина Шеремет, Харківський національний університет імені В. Н. Каразіна}

У статті досліджується вплив аскриптивних статусів студентів на хід їхньої професійної соціалізації. Розглянуто ознаки гетерогенності студентства як соціально-демографічної групи. Автори розглядають аскриптивні статуси як соціальні ознаки, що можуть обмежувати доступ студентів до здобуття вищої освіти. Зазначається низка аскриптивних статусів, що можуть мати обмежуючий вплив, а саме: стать, економічний та культурний капітали сім'ї, місце проживання перед вступом до закладу вищої освіти. Серед чинників професійної соціалізації зазначаються статусні позиції студентів, освітні диспозиції, зміст і спрямованість навчального процесу. Навчання студентів у ЗВО розглядається крізь призму набуття компетентностей, які вони отримують унаслідок реалізації освітніх практик. Професійна соціалізація розглянута як процес набуття професійних компетентностей у процесі виконання освітніх практик. Поняття освітньої практики застосовується з позиції конструктивістського структуралізму П. Бурдьє та визначається як рутинізовані, неусвідомлені акти, що повторюються в часі, та спрямовані на реалізацію стратегій ціледосягнення у певній сфері соціальної дійсності. Визначення ступеню впливу аскриптивних статусів на процес професійної соціалізації у ЗВО автори здійснюють за допомогою результатів кількісного опитування українських студентів (дослідження проведено у 2014/2015 pр., усього опитано 797 студентів українських 3ВО та 417 студентів польських 3ВО). Проаналізовано зв'язок між інтенсивністю освітніх практик, що сприяє залученості до навчального процесу, та академічною успішністю. З'ясовано та схарактеризовано наявність ієрархії освітніх практик з позиції їхної результативності. Автори доходять висновку щодо наявності залежності між аскриптивним статусним набором студентів та ступенем інтенсивності їхньої професійної соціалізації. Виявлено найбільшу «капіталомістськість» культурного капіталу сім’ї студентів порівняно $з$ іншими їхніми аскриптивними статусами.

Ключові слова: аскриптивні статуси, вища освіта, професійна соиіалізачія, освітні практики, конструктивістський структуралізм, студентоцентрована освіта 


\title{
Влияние атрибутивных статусов на интенсивность образовательной практики студентов
}

\author{
Роман Борисов, Ирина Шеремет, Харьковский национальный университет имени \\ В. Н. Каразина
}

В статье исследуется влияние аскриптивных статусов студентов на их профессиональную социализацию. Рассмотрены признаки гетерогенности студенчества как социально-демографической группы. Авторы рассматривают аскриптивные статусы как социальные признаки, которые могут ограничивать доступ студентов к получению высшего образования. Отмечается ряд аскриптивных статусов, которые могут иметь ограничивающее влияние, а именно: пол, экономический и культурный капиталы семьи, место жительства перед поступлением в высшие учебные заведения. Среди факторов профессиональной социализации указываются статусные позиции студентов, образовательные диспозиции, содержание и направленность учебного процесса. Обучение студентов в вузах рассматривается сквозь призму приобретения компетенций, получаемых в результате реализации образовательных практик. Профессиональная социализация рассмотрена как процесс приобретения профессиональных компетенций в процессе выполнения образовательных практик. Понятие образовательной практики рассматривается с позиции конструктивистского структурализма П. Бурдье и определяется как рутинизованные, неосознанные акты, повторяющиеся во времени, и направленные на реализацию стратегий целедостижения в определенной сфере социальной реальности. Авторы определяют степень влияния аскриптивных статусов на процесс профессиональной социализации в вузах на основании результатов количественного опроса украинских студентов (исследование проведено в 2014/2015 гг., всего опрошено 797 студентов украинских вузов и 417 студентов польских вузов). Проанализирована связь между интенсивностью образовательных практик, способствующей вовлеченности в учебный процесс, и академической успеваемостью. Выявлено и охарактеризовано наличие иерархии образовательных практик с позиции их результативности. Авторы приходят к выводу о наличии зависимости между набором аскриптивных статусов студентов и степенью интенсивности их профессиональной социализации. Обнаружена крупнейшая «капиталоёмкость» культурного капитала семьи студентов по сравнению с другими аскриптивными статусами.

Ключевые слова: аскриптивные статусы, высшее образование, профессиональная социализация, образовательные практики, конструктивистский структурализм, студентоцентрированное образование

\section{Introduction}

$\mathrm{I}$ $\mathrm{n}$ conditions of the information society establishment, the requirements for the training specialists with higher education significantly changed. First of all, it is true for the training of the innovator who is able to implement in practice the knowledge got during the process of the education, to update the knowledge permanently, to define the priority of the tasks within the sphere of the professional activity, make decisions and take the responsibility of their implementation, to work in team etc. The content of a young person's educational activity changes within a higher education institution (hereinafter referred to as HEI). Not only the passive reproduction of information got during the classes is expected from a student, but also the ability to formulate an own trajectory of the cultural capital acquiring, which is the base of the professional competences. The nature of the education at general education schools in many cases determines the situation when a teacher is almost the only agent of the cultural capital, successfully incorporated by students through the years of the studying at school. The studying at HEI requires a higher level of the engagement of the students in this process, especially under the establishment of the studentcentered education.

The content and the intent of the educational process, the educational dispositions (value orientations, motivation for educational activity, professional and the status plans etc.) of students and their status positions, ascriptive in particular, are the important factors of the professional socialization. It must be noted that the community of students is replenished by people from different segments of the population, different towns etc., therefore they have the unequal access to the economic, cultural, social and other kinds of the capital. At the same time, the gradual reduction of the number of State-funded places at HEI, which provide the possibility to pursue higher education "for free", is taking place. This actualizes the studying of the question whether the ascriptive statuses impact the course of the professional socialization. From our point of 
view, the ascriptive statuses should be considered as assigned social indicators, which influence the defining of actor's position in certain social fields of the society, regardless of which strategies are implemented and which practices are realized.

The theoretical-methodological underpinnings

The issue of the social, including ascriptive, statuses of a personality as the factor of the social stratification is covered in the research works of P. Blau, R. Bendiks, M. Weber, A. Gouldner, O. Danken, N. Kovalisko, O. Kutsenko, S. Makeev, G. Marshal, R. Linton, S. Lipset, O. Oksamitna, T. Parsons and other researchers. The differentiation of students by the separate ascriptive statuses is researched by a number of scientists, including sociologists, who turn to the study of the issues of the professional realization of a personality. However, the cumulative impact of the complex of the ascriptive statuses on the professional socialization of students still remains beyond the attention of researchers. The ascriptive statuses may both as restrict the results of certain actor's activities, as contribute to the enhancement of their effectiveness.

The purpose of the article is to define the impact of the ascriptive statuses of students on their educational practices. The "Students Of The Borderlands of the Central and East Europe: values, identity, life plans" sociological study is the empirical basis of the research. It was conducted by V. N. Karazin National University Department of Sociology (2014/2015 academic year, 797 Ukrainian students are interviewed, among them 508 are students of V. N. Karazin National University, 178 are students of Lesya Ukrainka Eastern European National University (Lutsk), 111 are students of Lutsk National Technical University and 417 are students of The University Of Zielona Góra (Poland); the leader of the study is Ph.D. in Sociology, professor L. Sokuryanska.

Must be noted, that after the implementation of External independent evaluation as the tool for measuring of the knowledge level, school leavers, who have different social origins, get the equal opportunity to enter an HEI. This fact, according to the authors and the implementors of the reforms, smooths out the possible impact of the economic capital of a family (which might be embodied, for example, in the corruption) on the chances for the entering. On the other hand, since families with different social and professional statuses possesses different volumes of the capitals (first of all, economic and cultural), as well as with regard to the uneven development of the infrastructure in
Ukraine, including the cultural and the educational ones, we believe the chances of the persons originating from different families to enter an HEI successfully are going to differ depending on their social positions.

Turning to the topic of the gender identity of young people, we note that the results of multiyear sociological studies show that girls are more motivated to study and demonstrate better academical performance, in comparison with young men. The traditional division on the students of the science and technology on one side, and arts on another is still actual by gender.

It is necessary to define the influence of the family on the worldview formation of a personality, including his or her social and professional plans, during the primary socialization. The starting opportunities and limits of a young person depend on the volume of the economic and social capital of his or her family, start with funds which are converted into a quality education within a specialized school, roll to the availability of the connections, which help to increase the chances of getting a desired social and professional status. In that regard, while researching a professional socialization, it is necessary to consider such characteristics of families' statuses, as the material conditions, the level of the parents' education and their place within the society's professional structure, the volume of the cultural capital. These status characteristics are ascriptive regarding to a student, because their availability do not depend on the actions of the actor.

Young people from different types of locality, from a village to a capital, enter the high school. The population, the sizes, the level of the urbanization and the infrastructure development in a certain locality define the level of the homogeneity of the local identity, a carrier of which each resident of the locality is. The local identity, in turn, determines the distribution of the set of norms and values. According to E. Durkheim, the more the division of labour is developed within a separate locality, the more functionally independent are the residents, the more often the manifestations of the organic solidarity can be seen within their relationships. While formulating the typology of the solidarity, E. Durkheim was guided by the relation between the restitute and the repressive norms, which are enshrined in legal and regulatory instruments. Thus, a society, in which the characteristics of the solidarity indicate the proximity to the mechanical type, is less inclined to allow visible, demonstrative 
deviations from norms and values, which constitute its monoculture. In such a community (which is small and is constituted by a network of personal acquaintances), the function of the social control is of great importance. A person, who lives in a society, which is characterized by the corresponding type of the solidarity, is considered not so much as a personality, which has a subjectivity, but rather as an individual, who belongs to the territorial community, and his or her identity almost does not differ from the identity of the other residents of the locality [13]. However, the representatives of such communities are more self-sufficient in terms of economy, are able to provide themselves with the livelihood and they often form housekeepings, which lifecycle only inconsequentially depends on the external connections. The status of the resident of a locality is ascriptive and determinates the specificity of the possession of a volume of the economic and cultural capitals, as well as the results framework and the set of the dispositions, which are embodied in the hierarchy of values and the motivation to study and to acquire trades. It is also important to pay attention to the different level of the quality of secondary education. According to the results of the study "The Impact Of The Social And Economic Environment On The Learning Outcomes of the students (pupils) Of General Education School", the results of External independent evaluation of students of urban schools are much better, in comparison with the rural students [18, p. 11].

While analyzing the educational practices of the students at HEI, it is important to keep in mind that we consider the process of the studying as a gradual absorption of a set of professional competencies. The British psychologist John Raven was one of the first among the researches who typologized the competencies and allocated the highly specialized knowledge, the substantive skills and the means of thinking and awareness of a person's own responsibility for his or her actions. The typology is based on the system of values and dispositions. We note that while providing the characteristic of the relation between the behavior and the motivation, J. Raven concludes that the relation is the result of the cooperation of such variables as "values, the components of competencies and social attitudes" [23, p. 261]. In our view, such allocation of the competencies is too narrow and does not provide systematic, since it contains the professional knowledge which belong to different specialties. Between such forms of knowledge, there is a lack of so-called "bridges. In the result of the process of the professional socialization, which takes place during the studying, a student not only gets the professional knowledge and forms the understanding of in which cases they can be applied and in which cases their applying can be dangerous (which is embodied, e.g. in the Codes of Ethics for different professions, such as a physician, a journalist, a lawyer, a sociologist etc.), but also changes the worldview. That is, besides the professional socialization, the educational institutions perform the function of worldview formation. In the case of the long-lasting lack of the experience of the applying of the special knowledges, got by a specialist, the knowledges gradually become forgot. And the process of the forgetting is the more faster, the more differentiated and far the special knowledges are from the knowledges the person applies regularly, including the daily experience. Thus, one of the possible solutions of the issue of the forgetting the knowledges, which are not actualized because of these or those reasons, is the formation of their relationship with the aim of the integration into a holistic system. Metaphorically saying, the foundation, the skeleton, the insurgent junction of such system are those elements of knowledge which are the most general types of knowledge. So, the models of the competencies, identified by J. Raven, should be supplemented by those which include the wide erudition both as within a separate specialization, as within the culture in general.

The process of getting the competencies performs as the result of the educational practices realization, in the definition of which we are basing, first of all, on the theoretically-methodological concepts of P. Bourdieu's Constructivist Structuralism. According to the conception, the practices are defined as the routinized unconscious acts, which are repeated in time and are aimed at the realization of the strategy of the achieving the goal within a certain sphere of social reality. We note that the practices, as $\mathrm{P}$. Bourdieu believes, are the result, on one hand, of the positions, which an agent takes through a set of personal social statuses, and of the dispositions, on the other hand, which are defined by P. Bourdieu as "the principles, which create and organize the practices and the perceptions, which could be objectively adapted to their aim, though do not involve the informed focus on it and irreplaceable harnessing of the necessary operations to achieve it" $[9$, p. 102].

While formulating the definition of the educational practices, we were directed by $P$. Bourdieu's conceptions, where they are defined as 
the habilitized practices, which are aimed to the harnessing of knowledges from the different spheres of science and are prompted by the valuable relation to the education, by the motivation and norms of the educational activity, by the emotional relation to studying. The practices, which indicates both as the process of studying at HEI, as the self-education, are considered by us as the educational ones. The practices of the studying are mostly linked with the process of education, which is organized directly by the educational institutions. The measure of the inclusion into the educational process is marked by the regularity of studying, the indicator of which is the visiting of classes, the volume of time, used for the study activities and exercises, the frequency of using of the additional search tools (the internet network etc.) for the preparing for both as home tasks, as well as for exams. The existence and regularity of the foreign languages studying practices beyond the educational process at HEI, using of them for reading the special literature, should be also attributed to self-education.

The basic indicator of the educational practices success, of the relevance of their consequences to the homology of the field of education, that is the requirements of such the agents of socialization as the educational institute in general and particularly the teachers, is the academic performance of students (since the heredity of the evaluation of pupils and students is in the focus of our analysis, we consider the academic performance not only at HEI, but also at school). Another indicator of the success is the measure of the impact of a student to the process of studying, the interest in the material, presented during the classes or in the educational and scientific literature, which is embodied in the assessment of the level of applying of personal efforts and capacities.

\section{Explanation of the results of the research}

The analysis of the one-dimensional distribution of the answers let us capture some distinction in the performing of the specified educational practices. In order to provide a more illustrated assessment of the level of the performing of practices we have created the index of the educational practice intensity, which is measured within a range between -1 and 1 . The results of the research shows that the most regular practice is the classes attendance, the index of what is 0.39 . A little bit lower is the regularity of student's studying during a semester and the full completion of the tasks (the indexes are equal to
0.35). The practice of the studying according to person's ability and capacity got the meaning of the index, close to 0 . In our view, such practice reflects the existence of the interest to studying on the part of a student, his or her motivation, and therefore the relevance of the got cultural capital to the existing student's dispositions. The negative meaning has the index of the practice of getting knowledges, which are connected with the training program but go beyond it. The existence of this practice reflects that some students use the got knowledges to increase them. The got knowledge, so-called informational resource can be a capital only in the case if its (re)producing is ensured. That is to say, the ensemble of the educational practices contains capital potential only in the case if positively correlate with the given practice. Thus, the indicator of the educational practice's capital potential is the existence of the correlation relationship with the work, with the educational material, which are included in the training program. We note that all the mentioned above educational practices reflects the existence of such correlation relationship with the sign under the research on the level 0.01. The intensity of the relationship varies according to the given practice. Thus, the working beyond the predetermined program in most cases is accompanied by the full applying of student's efforts and capacities (Spearman's correlation coefficient $\rho=0,49$ ). The remaining practices are also connected with this indicator, the meaning of the coefficient varies from 0.3 to 0.4 .

The influence of the time volume, which students use for the preparing to the classes, at their academic performance, was analyzed. The results of the study showed, that $2.8 \%$ of students do not prepare for the classes, $11.3 \%$ use less than an hour for the preparing, $28.7 \%$ use from one to two hours, $27.8 \%$ use from two to three hours, $16.6 \%$ use from three to four hours, while $12.8 \%$ use more than four hours. The volume of the time, which is dedicated by students to the studying beyond an educational institution, correlates with the considered above educational practices (the correlation coefficients are reliable on the level of 0.01 , the intensity of the relationship varies from 0.248 to 0.37 ), as well as with their indicator, which is the academic performance (Spearman's correlation coefficient is significant on the level of 0.01 , the intensity of the relationship is $\rho=0,284)$. Thus, among the students, who tend to focus on academic pursuits for 3-4 hours per day, 
about $11 \%$ are "straight $\mathrm{A}$ " students (in general within the array the meaning is $9 \%$ ), $71 \%$ are "B-students" ((in general within the array the meaning is $59 \%$ ).

According to the results of the research, the performance of students at HEI, in general, is quite high and does not correspond to a normal distribution. $9 \%$ of students say they are straight A students, about $60 \%$ get both A's and B's, about $21 \%$ mostly get B's, about $10 \%$ mostly get B's and C's, $1 \%$ in most cases get C's. After analyzing the academic performance of the students while they were at school, we have elicited a slight decreasing of the performance, if to compare the two periods of education: at HEI the ratio of straight A students decreases twice ( $9 \%$ and $21.5 \%$ respectively), the ratio of "C-students" and those who get A's and B's in most cases, decreases almost twice (about $11.2 \%$ and 5.4\% respectively). The existence of the significant correlation between the marks in school and in HEI reflects the actuality of the tendency of the reproduction of the school academic performance at HEI.

It should be noted that the regularity of the considered above educational practices is the keystone to the high academic performance at HEI. The results of the correlation analysis helped us to draw conclusions about the existence of the hierarchy of the educational practices regarding their result, recorded by the marks of the performance (the hierarchy is presented below in the order from the most influential educational practice to the least influential one):

1) classes attendance (Spearman's coefficient $\rho$ $=0.435$, the significance on the level 0.01);

2) the study with the full applying of student's efforts and capacities (Spearman's coefficient $\rho=$ 0,42 , the significance on the level 0.01);

3 ) educational tasks implementing (Spearman's coefficient $\rho=0.398$, the significance on the level 0.01 );

4) the regularity of studying during a semester (Spearman's coefficient $\rho=0.348$, значущість на рівні 0.01);

5) the work beyond the predetermined training program (Spearman's coefficient $\rho=0.29$, the significance on the level 0.01);

6) the allotted time for the preparing for the classes (Spearman's coefficient $\rho=0.284$, the significance on the level 0.01);

7) the allotted time for the preparing for tests and exams (Spearman's coefficient $\rho=0.183$, the significance on the level 0.01);

8 ) reading the special literature on a foreign language (Spearman's coefficient $\rho=0.147$, the significance on the level 0.01);

9) searching the material to do home task within Internet (Spearman's coefficient $\rho=0.106$, the significance on the level 0.01).

The relationship of the academic performance with the other educational practices is not intensive (Spearman's coefficient $\rho<0.1$ ) or does not exist at all.

While studying the influence of ascriptive statuses at the intensity of educational practices, we have elicited a number of dependencies. Thus, there are distinctions in the realization of educational practices by young men and women. Usually, such practices are characterized by the necessity of having responsibility and discipline. Girls more often than boys claims that their practices include or rather include the regular studying during a semester $(68.4 \%$ and $58.6 \%$ respectively), the regular classes attendance ( $73.5 \%$ and $57.2 \%$ respectively), as well as the complete educational tasks implementing (about $70 \%$ and $53.5 \%$ respectively). However, we have not elicited the distinctions by sex regarding such educational practices, that are connected with the readiness to work beyond the predetermined program and the level of involved efforts, the applying of a student's abilities during the studying process. The results show that in the case of facing with the necessity of creative realization of tasks during the studying there are no differences in the success of the implementation by girls and boys. Therefore, the differentiation by sex influence the intensity of educational practices, but not at the level of their cultural saturation, which is defined by the intensity of knowledge through the autonomous getting of new competencies. From this position, the sex status is "egalitarian" from the point of the influence at the reproduction of the cultural capital.

The regularity of student's educational practices, who come from small settlements, statistically does not differ from the regularity of the "urban" students' educational practices. According to the results of the research, conducted in 2013-2014, the performance of the students from small settlements during the studying at a general education school (for details see) was higher in comparison with the performance of students from big cities. The academic performance of both groups of students at HEI does not differ statistically. This demonstrates, that, first, the quality of the education at school in a little town is lower than the quality of the education 
at an urban school, secondly, the intensity of the educational practices of students of the both groups, despite of the relatively worse positions while the entering and during the first grade, moves into "alignment" by the third and fourth year of study.

\section{Conclusions}

We now turn to the definition of the influence of the cultural capital of a family at the intensity of students' educational practices and their academic performance. The results of the research showed that the education of a father is the least influential factor of the educational success and practices. Thus, a weak link between the academic performance and the level of the education was elicited: the more is the educational level, the better is the performance of a student. A mother's educational level is a little bit more influential not only regarding the performance at HEI (though in this case, the power of the link is higher and more reliable) but also regarding the practice of regular studying during a semester. The cultural capital of the family, recorded in its objectified state as the number of books in a family, determines both as the academic performance (both at HEI and at school), as well as some educational practices: the regularity of studying during a semester and the work beyond the predetermined training program, and also reflects the success of the educational practices, which is embodied in the process of self-actualization during the studying (the full applying of student's efforts and capacities).

\section{REFERENCES}

1. Ames, C., \& Archer, J. (1988). Achievement goals in the classroom: Students' learning strategies and motivation processes. Journal of educational psychology, 80(3), 260.

2. Archer, M., \& Lemert, C. (2002). Being human: The problem of agency. INTERNATIONAL REVIEW OF MODERN SOCIOLOGY, 30(1).

3. Bauman, Z. (2003). Intimations of postmodernity. London: Routledge.

4. Bakirova, V. S. (Ed.). (2015). Bar'ery modernizacii vysshej shkoly Ukrainy [Barriers to the modernization of higher education in Ukraine]. Kharkiv.: HNU imeni V.N. Karazina [in Russian].

5. Lipset, S. (2018). Social mobility in industrial society. London: Routledge.

6. Blau, P. M., \& Duncan, O. D. (1967). The American occupational structure. New York : Wiley

7. Borysov, R. I., \& Sheremet, I. I. (2013). Socialjno-demoghrafichni chynnyky profesijnoji socializaciji studentiv [Socio-demographic factors of professional socialization of students]. Visnyk Kharkivsjkogho nacionaljnogho universytetu imeni V. N. Karazina. Sociologhichni doslidzhennja suchasnogho suspiljstva: metodologhija, teorija, metody, 30, 186-194 [in Ukrainian].

8. Borisov, R., \& Sheremet, I. (2014). Uchebnye praktiki shkol'nikov Har'kovshhiny: pokazateli, dinamika, faktory aktualizacii [Educational practices of students in Kharkov region: indicators, dynamics, factors of actualization]. Ukrajinsjkyj sociologhichnyj zhurnal, 1-2, 70-78 [in Russian].

9. Bourdieu, P. (2016). Choses dites. Minuit.

10. Bourdieu, P. (2007). Reproduction elements for a theory of the educational system. M.: Prosveshhenye [in Russian]. 11. Deyneko, O. (2013). Proressional risks of modern students as a component of a risk society: risks peculiarities of the professional existence phases. Ukrainian society, 4 (47), 26-38.

12. DiMaggio, P. (1982). Cultural Capital and School Success: The Impact of Status Culture Participations on the Grades of U.S. High School Students. American Sociological Review, 47 (2), 189-201.

13. Dyurkgeym, E. (1996). O razdelenii obschestvennogo truda [On the division of social labor]. Moskva: Kanon [in Russian].

14. Foladar, I. (1969). A Clarification of "Ascribed Status" and "Achieved Status". The Sociological Quarterly, 10 (1), 53-61.

15. Goldtorpe, J. \& Erikson, R. (1992). The Constant Flux Oxford: Clarendon Press.

16. Goode, W. (1957). Community Within a Community: the Professions. Sociological Perspectives on Occupations American Sociological Review, 22 (2), 194-200.

17. Hall, R. (1983). Theoretical Trends in the Sociology of Occupations Sociological Quart. Retrieved from: http:// www.jstor.org/stable/2088857.

18. Vpliv sotsialno-ekonomichnogo seredovischa na rezultati navchannya uchniv (vihovantsiv) zagalnoosvitnih navchalnih zakladiv [Influence of socio-economic environment on the results of education of pupils of secondary schools]. (2016). Institut osvitnoyi analitiki. Retrieved from: http://testportal.gov.ua/wp-content/uploads/2017/01/ zvit_oputyv_2016.pdf [in Ukrainian].

19. Kerckhoff, A. (1976). The Status Attainment Process: Socialization or Allocation? Social Forces, 55 (2), $368-381$. 20. Konstantinovskiy, D., \& Popova, E. (2015). Molodezh, ryinok truda i ekspansiya vyisshego obrazovaniya [Youth, labor market and expansion of higher education]. Sotsiologicheskie Issledovaniya (11), 37-48 [in Russian].

21. Maloshonok, N., \& Semenova, T., \& Terentev, E. (2015). Uchebnaya motivatsiya studentov rossiyskih vuzov [Academic Motivation among Students of Russian Higher Education Establishments: Introspection]. Vozmozhnosti teoreticheskogo osmyisleniya. Voprosyi obrazovaniya (3), 93-121 [in Russian]. 
22. Nock, S., \& Rossi, P. (1978). Ascription versus Achievement in the Attribution of Family Social Status. American Journal of Sociology (3), 565-590.

23. Raven, D. (2002). Kompetentnost v sovremennom obschestve: vyiyavlenie, razvitie i realizatsiya [Competence in modern society: identification, development and implementation]. Moskva: Kogito-Tsentr [in Russian].

\section{Борисов Роман Ігорович}

Кандидат соціологічних наук

Харківський національний університет імені

В. Н. Каразіна

61000, Харків, майдан Свободи, 4

Email: r.i.borysov@karazin.ua

\section{Шеремет Ірина Іванівна}

Кандидат філософських наук, доцент

Харківський національний університет імені

В. Н. Каразіна

61000, Харків, майдан Свободи, 4

Email: r.i.borysov@karazin.ua

\author{
Borysov Roman \\ Ph.D. of Sociology \\ V. N. Karazin Kharkiv National University \\ 4, Svobody sq., Kharkiv, 61000, Ukraine
}

\section{Sheremet Iryna}

Ph.D. of Philosophy, Assoc. Prof.

V. N. Karazin Kharkiv National University

4, Svobody sq., Kharkiv, 61000, Ukraine

Цитування: Борисов Р. І., Шеремет I.І. Вплив статусів припису на інтенсивність навчальної практики студентів/ Р. І. Борисов // Науково-теоретичний альманах «Грані». - 2019. - Т. 22 . - № 8. - С.29-36.

Citation: Borysov, R.I.\& Sheremet I.I. (2019). Vplyv statusiv prypysu na intensyvnist navchalnoi praktyky studentiv [The influence of the ascriptive statuses at the intensity of students' educational practices]. Scientific and theoretical almanac «Grani», 22 (8), 29-36. 